\title{
A REPRESENTAÇÃO IMAGÉTICA DA JUSTIÇA NA IMPRENSA ANARQUISTA BRASILEIRA
}

Alberto Gawryszewski

\begin{abstract}
RESUMO: O presente texto visa estudar como a imprensa anarquista brasileira desenhou a "justiça burguesa" em seus periódicos, no período 1890-1930. Para a compreensão das charges e caricaturas anarquistas, vai se adotar o conceito de charge ideológica, uma produção visual sem fronteiras, atemporal, agressiva e crítica, onde o riso não era sua essência.
\end{abstract}

PALAVRAS-CHAVE: Anarquismo. Imagem. Movimento Operário.

ABSTRACT: This study aims to analyse how the Brazilian anarchist press designed "bourgeois justice" in its periodicals, in the period 1890-1930. To better understand cartoons and anarchist caricatures, the concept of ideological charge is adopted, a visual production without frontiers, timeless, aggressive and critical, where laughter was not its essence.

KEYWORDS: Anarchism. Image. Worker Movement.

RESUMEN: El presente texto pretende estudiar cómo la prensa anarquista brasileña diseñó la "justicia burguesa" en sus periódicos, en el período 1890-1930. Para la comprensión de las caricaturas anarquistas, se va a adoptar el concepto de cargo ideológico, una producción visual sin fronteras, atemporal, agresiva y crítica, donde la risa no era su esencia.

PALABRAS CLAVE: Anarquismo. Imagen. Movimiento Obrero.

\section{Introdução}

A questão central desenvolvida neste trabalho de pesquisa foi discutir o uso da representação imagética do Poder Judiciário (a Justiça) por meio das ilustrações (desenhos, caricaturas e charges) na imprensa anarquista brasileira, no período compreendido entre os anos de 1889 e 1930. Entenda-se imprensa anarquista os jornais editados na cidade do Rio de Janeiro e de São Paulo que se intitulavam anarquistas, vinculados ou não ao meio sindical.

Este trabalho foi dividido em duas partes básicas. Na primeira, História e fontes, vêse, rapidamente, a criação das revistas ilustradas no Brasil, a primeira caricatura publicada e sua relação com a história. Faz-se necessário tal apresentação pela simples razão de se compreender que a imagem, a ilustração crítica, já se fazia presente na vida cotidiana brasileira. Serão apresentados os conceitos historiográficos utilizados por este trabalho, como também as fontes. A segunda parte trata da representação da Justiça (em sentido amplo), do Poder Judiciário (interprete e agente do Estado) e das leis (Poder Legislativo) nos periódicos da imprensa anarquista, e de como se usou a imagem para criar e propor uma ideologia (sociedade anarquista) e apresentar críticas aos poderes (autoridades) estabelecidos. Aqui,

\footnotetext{
* Professor Associado " $C$ " do Departamento de História da Universidade Estadual de Londrina (UEL). Professor Permanente do Programa de Pós-Graduação em Comunicação da UEL.
} 
não podemos esquecer o poder repressivo, baseado ou não nas leis, dos poderes executivos estaduais e federal (muitas vezes em conluio com as agências patronais).

\section{História e fontes}

A primeira caricatura reconhecida e aceita foi publicada no Jornal do Comércio, de 14 de dezembro de 1837, tendo por autoria Araújo Porto Alegre. Uma das primeiras revistas especializadas na arte visual caricata foi Semana llustrada, lançada em 1860, pelo alemão Fleiuss. Marcando época, essa revista sobreviveu por dezesseis anos consecutivos, gerando o aparecimento de diversas outras no gênero. Em seu extenso trabalho sobre a caricatura no Brasil do século XIX, Lima (1963) listou as principais revistas ilustradas e os seus principais desenhistas. Na Figura 1, capa da revista $O$ Lobishomem ("ilustração caricata de comprimentos e cortezias"), de 1870, podem-se visualizar as revistas concorrentes à mesma, tais como Comédia (Social?), Vida Fluminense, O Mosquito, Semana Illustrada, Rabeca. Vêse, portanto, que as revistas que possuíam ilustrações caíram no agrado do público e puderam produzir imagens impactantes sobre o período. Segundo Lima (1963, p. 131), O Mefistófeles, O Lobishomem e a Comédia Social seriam incorporadas pela O Mosquito, que, por sua vez, foi incorporada à Revista Ilustrada em 1877, demonstrando uma dinâmica no mercado editorial para atender a uma demanda de competitividade e à sua própria subsistência.

\section{Figura 1}

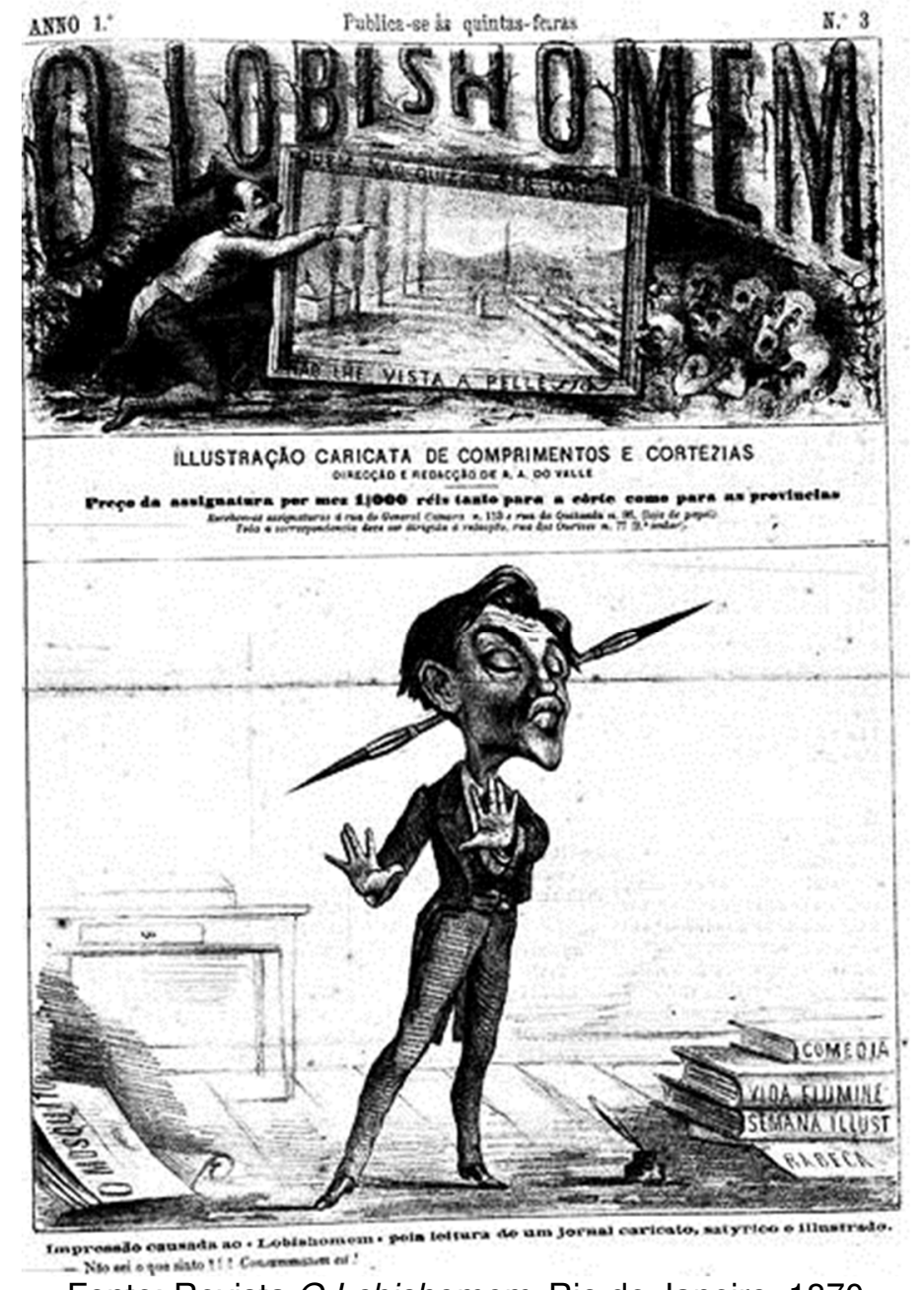

Fonte: Revista O Lobishomem, Rio de Janeiro, 1870 
Com uma rápida passagem de olhos nas páginas desses periódicos, podemos encontrar imagens em que a Justica e o Poder Judiciário se fizeram presentes. A Revista Ilustrada, que tinha por objetivo atingir o poder monárquico, o poder político (Congresso), a Igreja e a escravidão negra instituída, não colocou o Poder Judiciário entre seus principais inimigos. Apresentam-se duas imagens que dão uma ideia da posição da revista e sua forma de abordar os temas tratados. A Figura 2 é um exemplo do tipo de crítica direta executada. Nela, vemos o índio, que representava a nação brasileira, e o Tesouro Nacional (o barril) necessitando de seu sangue. Da mesma maneira, o Senado e a Câmara, na forma de sanguessugas, absorvem o pouco de força que sobraria para o "índio". Abaixo, uma legenda bem explicativa: "Coitado! Com tal médico e tais remédios... não irá longe".

Figura 2

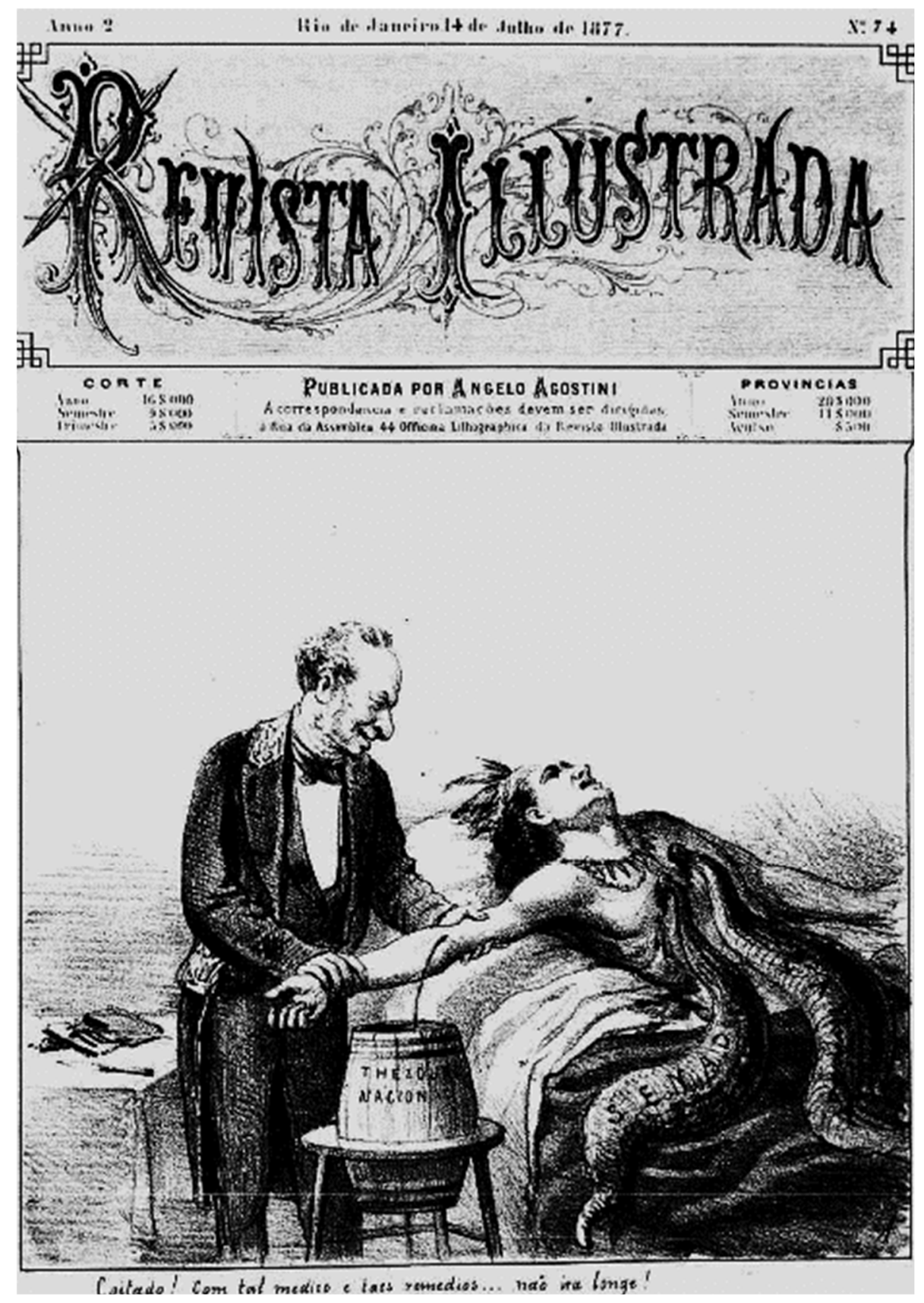

Fonte: Revista Illustrada, Rio de Janeiro, 14 jul. 1877. 
Portanto, o poder político é uma máquina a destruir o potencial do povo brasileiro. $\mathrm{Na}$ Figura 3, uma crítica direta à Justica, representada por um homem obeso com as vestes caracteristicas do juiz do Poder Judiciário. A imagem, que muito bem poderia ter sido publicada na revista ilustrada O Malho, de 1906, ou Fon-Fon, de 1921, bem como na imprensa operária anarquista, de 1917 (como veremos), apresenta a destruição da estátua da deusa Themis, a forma feminina da Justiça. Tudo o que ela representava (ver discussão dos signos mais adiante) foi destruído. Ao chão, outra representação feminina ("A Inocência", conforme escrito em sua roupa), pedindo clemência ao todo poderoso juiz - este usando dois símbolos pertinentes a Themis, a espada em suas mãos e a venda cobrindo apenas um dos olhos. Obeso e feliz, recebe de um ser sinistro, ao fundo da cena, um saco de dinheiro. A mensagem é clara, pois aos poderosos é dada a possibilidade da compra da sentença e ao inocente é dada a garantia da culpa. De justa, a Justiça brasileira como era, nada tinha. Para a Revista Ilustrada, a crítica era a realidade da Justiça, não a existência de um Poder Judiciário, mas a de um poder corrompido.

\section{Figura 3}

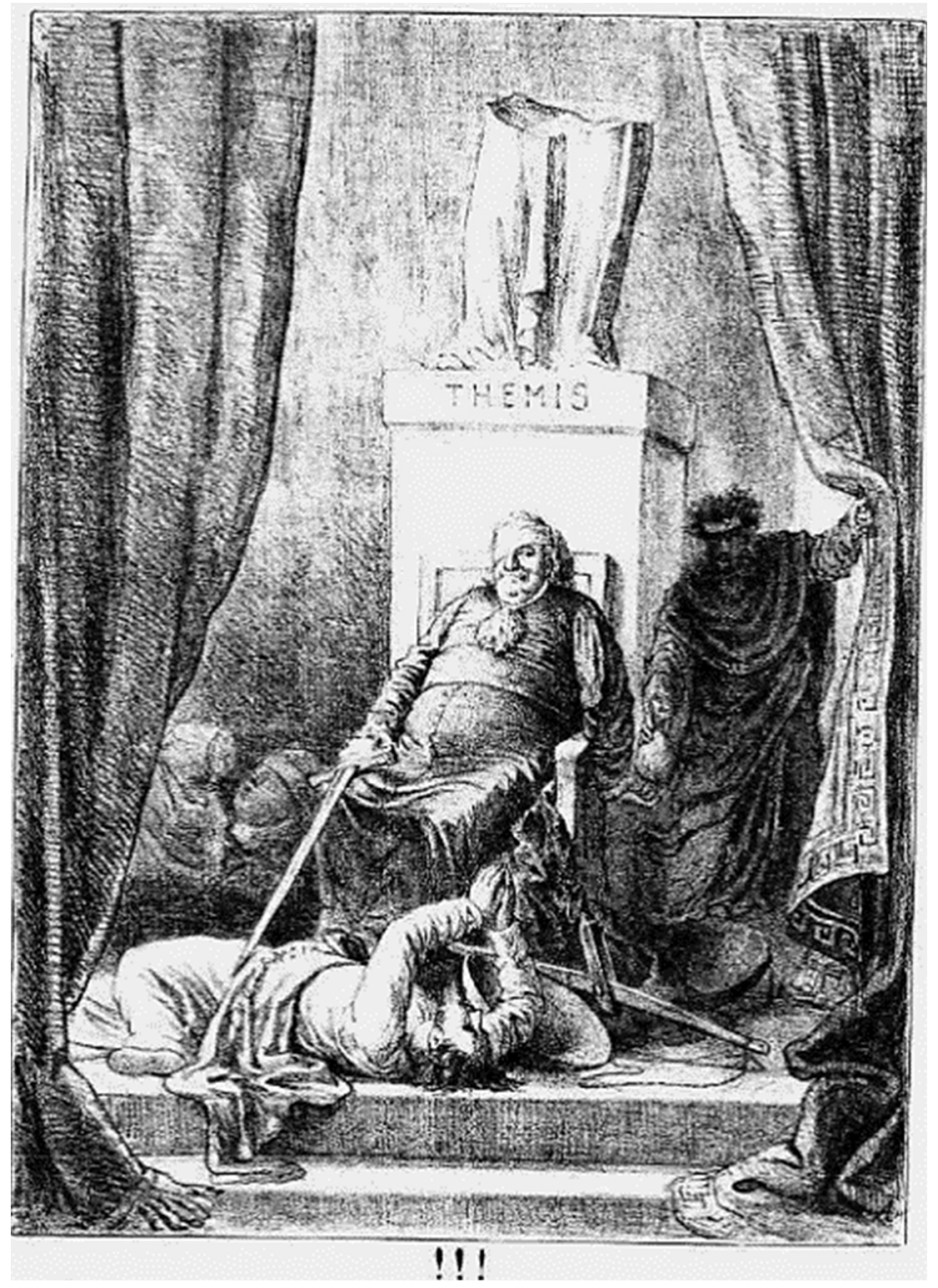

Fonte: Revista lllustrada, Rio de Janeiro.

No final do século XIX e início do século passado, surgiram diversos periódicos tendo a caricatura/charge como seu instrumento principal de divulgação e/ou divertimento. A grande imprensa diária passou a contar, em especial, a partir da década de 20 do século XX, com a 
contribuição de caricaturistas, nas suas diversas formas de manifestação (charge, gravuras etc.). Se, no século XIX, as críticas políticas às instituições eram uma constante, não foi novidade para a imprensa operária e anarquista a manutenção das mesmas, agora com um novo viés ideológico. Assim, a arte visual com esses formatos passou a fazer parte do cotidiano brasileiro.

Não há consenso sobre a existência de uma arte anarquista, embora muitos artistas se intitulassem como pertencentes a esse grupo de pensamento. É possível falar de uma estética anarquista (RAGON et all, 2001)? Da mesma forma, não se pode ter certeza ou clareza dos limites de uma obra gráfica anarquista. Quais limites devem ser estabelecidos? Como perceber em uma ilustração da imprensa operária seu viés político? Seria anarquista, anarco-sindicalista, socialista, "amarelo", ou apenas uma ilustração de senso comum contra um sistema capitalista altamente espoliador e repressivo? Boa parte da historiografia, baseada em relatos nos próprios jornais (balanços e notícias), apresentou os jornais operários e anarquistas como deficitários. Esse problema, somado à forte repressão, obrigou ao fechamento prematuro de muitas publicações. Para este trabalho, como já foi escrito, far-seá o uso de diversos jornais brasileiros e alguns estrangeiros.

Como a imprensa anarquista e operária não visava ao lucro, sua manutenção se dava pela via da venda avulsa, publicidade, assinaturas e subscrições, realizações de piqueniques, conferências e bailes. Muitas das imagens utilizadas nos periódicos operários e anarquistas eram reproduções de outros jornais, brasileiros e estrangeiros, denotando uma particularidade da imprensa de então. Mas quem são os desenhistas da imprensa operária e anarquista? Muitas das obras não possuem assinatura, seja por precaução do autor, seja por desinteresse do jornal ou do artista. Muitas das ilustrações que possuem assinatura são de autores não identificados. Enfim, a grande maioria das imagens é de desconhecidos. Mas teriam sido obras encomendadas em sua origem? Seriam os desenhistas remunerados por elas? Seriam da imprensa anarquista, propriamente dita? Enfim, muitas perguntas não respondidas.

Partimos da hipótese de que os artistas comungavam dos ideais da imprensa que utilizava sua obra, e de que eram engajados politicamente. Portanto, além de não discordarem de suas publicações, ainda produziam mais obras com o fito de denunciar fatos que consideravam relevantes. Consideravam sua obra como importante instrumento de educação política dos leitores dos jornais. Por fim, que a ilustração produzida representava um sentimento coletivo, único. Sendo eminentemente política, a obra imagética, em especial a charge, não tinha no riso um aspecto fundamental, em se tratando de charge e/ou caricatura. Talvez visasse apenas construir uma imagem negativa do objeto retratado (ou desconstruir, se positiva). Sua percepção é de um tempo preciso, revelando um fato, algo, em um espaço e lugar. Mas um aspecto fundamental na obra do artista e intrínseco ao pensamento anarquista é a liberdade de criação. A direção do jornal, se é que se poderia chamar de "direção", não deveria conduzir a produção da obra. Evidentemente, poder-se-ia pensar em sua não publicação caso não se adequasse ao posicionamento do jornal, mas isso é outra discussão, difícil de se comprovar, e uma violência ao ideal anarquista.

A imagem, para a imprensa operária, em especial anarquista, tinha por fito conscientizar seu leitor para uma situação que o mesmo vivia, mas que não conseguia ver como um problema coletivo, de classe, resultado da existência de um sistema opressor. Da mesma forma, havia a possibilidade da extinção dessa sociedade com o surgimento de outra forma de sistema político, econômico e social. Portanto, além de uma proposta de crítica social, de denúncia e de conscientização, a imagem carregava um novo ideário, uma resposta objetiva, não a crítica pela crítica, ou mudanças menores no sistema então vigente. Boa parte das ilustrações tinham destaque nas publicações, visto estarem na primeira página, a de maior visibilidade.

$\mathrm{Na}$ presente pesquisa se pôde verificar a existência de poucas imagens (desenhos, fotografias, charges e caricaturas), considerando a grande quantidade de jornais impressos. Mesmos nos jornais ditos "burgueses", a presença de caricaturas e charges não era tão 
comum, embora no início de século XX tal arte tenha começado a se expandir, inclusive conquistando a primeira página (Gazeta de Notícias, da cidade do Rio de Janeiro, por exemplo). Embora o avanço da tecnologia gráfica tenha possibilitado o barateamento do uso de imagens pela imprensa, para a operária e anarquista, acreditamos, o custo ainda era elevado. Apenas os jornais anarquistas que conseguiram ter uma vida mais longa poderiam usufruir de forma mais sistemática do uso de charges (A Plebe, por exemplo).

Quanto à relação da ilustração com o texto jornalístico, pode-se dizer que nem sempre a imagem ilustrava uma reportagem ou coluna. A imagem poderia possuir um texto e /ou uma legenda, o que ajudava na identificação dos personagens, da situação e, mesmo, da mensagem pretendida. Como havia uma proposta clara de denúncia e difusão de um ideal, como já escrito, a imagem poderia ter sua independência em relação ao texto jornalístico ou estar diretamente ligada a outro na mesma página, número ou outro exemplar da publicação. A imprensa, nesse sentido, deve ser vista como um processo educativo, em que as sequências se somam. Inclusive, foi possível encontrar imagens repetidas, mesmo que com grande espaço de tempo, visto que sua mensagem, razão de ser e seu objeto, ainda permaneceriam atuais. Estas poderiam ser reproduções de outras publicações, inclusive internacionais. Destaca-se a possibilidade de adaptação da imagem, em especial do texto contido, para os leitores brasileiros.

Ao analisarmos as imagens produzidas, temos que ter claro que o objeto desta pesquisa, o Poder Judiciário, é um poder instituído e, como tal, pode ou não estar servindo a determinada classe. Na charge da Revista llustrada (Figura 3), a Justiça como estava constituída servia aos graúdos, aqueles que poderiam comprá-la com um saco de dinheiro. Para o anarquismo, era uma estrutura de poder e repressão (legislação específica foi produzida para reprimir o movimento operário, essencialmente anarquista) a ser denunciada e combatida, como veremos a seguir. Mas, para outras empresas jornalísticas, o sistema judiciário era um bem essencial para o funcionamento da democracia brasileira.

Considerando que, no início da República, uma grande parte da população residente no Brasil era analfabeta, o uso de ilustrações era fator importante para a venda da publicação, seja na forma de divertimento, seja na forma de informação. Para a imprensa operária e anarquista, a visão de que a imagem era fator importante para a educação política dos trabalhadores não pode ser ignorada. Portanto, como escrito acima, era uma arte engajada, política.

Nesse sentido, a caricatura, a gravura e outras expressões da arte visual devem ser encaradas como importantes instrumentos de trabalho do historiador para estudos deste tipo. Tanto a imprensa engajada politicamente, como a de humor ou a burguesa, apresentam uma visão social, crítica e política do objeto desenhado. No caso específico da imprensa anarquista, política em sua essência, os sentimentos do artista acompanham suas perspectivas políticas e ideológicas frente aos poderes estabelecidos formalmente, ou seja, uma estrutura de poder oficial, como o Poder Judiciário, o Legislativo e o Executivo. Os três, em conjunto, utilizando-se de variadas formas para reprimir o movimento operário, seja pela confecção de leis, prisão, contenção de passeatas, violência contra as manifestações, proibições de greves, entre outras formas. Está-se, portanto, manuseando um olhar específico, abrindo novos horizontes para se compreender esse momento.

Mas o que significam a charge e a caricatura? Como conceituá-las? A primeira percepção que vem à mente quando se fala em charge ou caricatura é a existência do riso. Nas imagens que veremos a seguir, será difícil encontrar o riso. Este visa, em uma imagem crítica, à desconstrução do inimigo, à denúncia de um estado real, de uma situação contraditória. As ilustrações anarquistas têm essas características, mas não visam ao ridículo, ao cômico e ao riso. O desnudamento de uma realidade cruel propunha a construção de uma visão do mundo via um novo ideário, o anarquista. Dentro de uma charge pode haver, e em geral há, uma ou várias caricaturas. E é muitas vezes onde se encontra o riso. No caso da pesquisa em questão, ver-se-á que pouco há de caricatura. 
A historiografia nacional e estrangeira (ABREU, 2001; GAWRYSZEWSKI, 2008; LIMA, 1965; CARMONA, 2003; SOUZA, 1986) aponta para a existência de diversos tipos de caricaturas/charges: de costumes, social, política ou ideológica, entre outras. Às vezes, a caricatura é composta de título, imagem e uma legenda. O último componente reforça e/ou complementa a imagem, dando-lhe sentido, atingindo mais diretamente o caricaturado ou uma situação cotidiana da população. Ou seja, os componentes ajudam o receptor a entender de forma clara o objetivo proposto com o desenho elaborado. No desenho político e/ou satírico, a participação da legenda e, mesmo, do texto, poderá exercer importante função, ou seja, pode-se encontrar uma forte interação. Em geral, o desenho político sintetiza a mensagem do texto.

Acatamos a definição de charge ideológica para este texto, ou seja, construção de imagens voltadas ao embate político, visando as transformações políticas, econômicas e sociais. São produções imagéticas mais duradouras, extrapolando os limites territoriais, com forte carga agressiva, desnudando os inimigos e defendendo uma nova proposta de sistema político (GAWRYSZEWSKI, 2008, p. 24).

A associação entre seres inanimados e o homem é uma das armas utilizadas pela caricatura para degradar a imagem do atingido. O caricaturado pode ser retratado como fruta, vegetal etc. Pode, igualmente, ao contrário, dar vida a seres inanimados, associando-os à figura do homem. Assim, eles podem falar, andar, comentar, elogiar ou, principalmente, criticar uma situação do cotidiano. Mas animais e outros seres vivos também podem ser úteis para o artista, uma vez que este os retrata também com atributos humanos ou simbolizando algo bem maior, como um sistema político e econômico. No caso deste trabalho, o leitor irá visualizar o pouco uso dessa forma.

A figura feminina de Themis como representação da Justiça/Poder Judiciário é popularmente conhecida e aceita. Geralmente, é vista com vestes brancas, com olhos vendados e com a mão esquerda segurando uma espada e na mão direita uma balança em equilíbrio. Cada componente da imagem tem um significado: a espada representa força, prudência, ordem e regra; a balança, com o fiel ao meio, um equilíbrio igualitário, representa equidade, justeza das decisões; a venda, imparcialidade e objetividade; os olhos abertos vão na direção de uma observação atenta, da aplicação da lei sem descuido.

Outra marca do Judiciário é a toga, vestimenta usada pelos juízes e advogados nos tribunais. Com um desenho (design) específico, de cor preta, é facilmente identificável pelo leitor da imagem. Junto com a figura da Themis, o juiz togado foi outra representação da Justiça e do Poder Judiciário brasileiro.

Um conceito caro neste texto é o de "imaginário social", pois, ao conceder uma identidade, a coletividade distribui os papéis e as posições sociais; fortalece crenças comuns e constrói códigos de comportamento entre seus membros, para poder fixar uma imagem boa de si e má de seu inimigo (BACZKO,1985, p. 309). Dentro desse pensamento, a justiça ou a Justiça instituída é um dos parâmetros estabelecidos pela coletividade. Há um discurso de justiça e um poder de Justiça. As ilustrações, caricaturas e as charges vão estabelecer essa relação. Esse aspecto será importante neste texto, uma vez que se discute como os anarquistas, por meio de seus periódicos, como visão de coletivo, vão denunciar a sociedade burguesa capitalista, daí sua justiça burguesa, como opressora e desleal. Vão propor, ao contrário, uma sociedade nova, formada por uma nova coletividade, novos homens e novas mulheres, unidos para um bem comum.

Para este texto foram utilizados jornais que se intitulavam anarquistas, vinculados ou não ao meio sindical, editados nas cidades do Rio de Janeiro e São Paulo (exceção de Terra Livre, editado em Lisboa), que traziam no seu interior ilustrações que ajudavam a compor o ideário anarquista. Neste sentido, os jornais A Plebe, A Lanterna, A Liberdade, Guerra Social adquiriram papel importante neste trabalho. Outros, que não possuíam imagem, ajudaram na compreensão da percepção do pensamento anarquista brasileiro. 


\section{Imagem da "justiça burguesa" nos periódicos anarquistas}

Crime de rico, a lei o cobre,

O Estado esmaga ao oprimido: Não há direitos para o pobre,

Ao rico tudo é permitido.

(Trecho do hino "A Internacional").

O objetivo desta parte do texto é apresentar como o Poder Judiciário e as leis foram abordadas pelas imagens publicadas na imprensa anarquista. A epígrafe acima, do hino internacional do movimento operário, apresenta vários aspectos e conceitos que devem ser analisados. Primeiro, o pobre é sinônimo de oprimido, um cidadão sem direitos (não necessariamente relacionados com a lei); segundo, em contraponto, há o rico, a quem tudo é permitido, pois a lei o cobre. Isso com amplo espectro, pois se protege não só com as leis, como também apesar das leis, ou seja, caso o rico violente a lei, não irá responder por tal ato.

Destaca-se que o ideal anarquista teve forte influência no movimento operário brasileiro em fins do século XIX até meados dos anos 20 do século XX, quando perdeu espaço para o movimento comunista. No decorrer desse período, atuou em muitos sindicatos pelo Brasil, em especial nas regiões Sul e Sudeste. Editou livros, revistas, jornais e outros impressos. Foi perseguido, com apreensão e invasão das redações e maquinário de sua imprensa, prisão de jornalistas e operários, bem como morte e expulsão do território brasileiro de seus componentes.

Como fonte de informações, utilizou-se das reportagens e das charges (a maior parte de ilustrações no formato de desenho), uma vez que, pelo seu aspecto político-ideológico, a imprensa anarquista possuía características distintas da imprensa comercial "burguesa". Como já explicado em outro tópico deste trabalho, será utilizado o conceito de charge e caricatura ideológica para atender às demandas de análise desse perfil de produção cultural: imagem com agressividade por essência, sem necessariamente causar humor, mas com construção irônica que visa denunciar o caráter do retratado ou da situação retratada, com o uso do grotesco, da zoomorfia, de símbolos políticos, religiosos e outros. No decorrer do texto, essas questões serão retomadas e ampliadas com relação ao uso de textos na imagem.

Por seu ideário, o anarquismo não aceitava a democracia burguesa como expressão popular e legítima de estrutura política e, muito menos, o sistema capitalista como agente construtor de uma sociedade igualitária. Uma das charges (ou ilustração) mais reproduzidas na imprensa anarquista no período deste estudo foi a Figura 4 ( $A$ Plebe, São Paulo, ano 1, n. 9, 11 ago. 1917, p. 1; ou Guerra Social, Rio de Janeiro, n. 1, 11 ago. 1911, p. 1). 
Figura 4

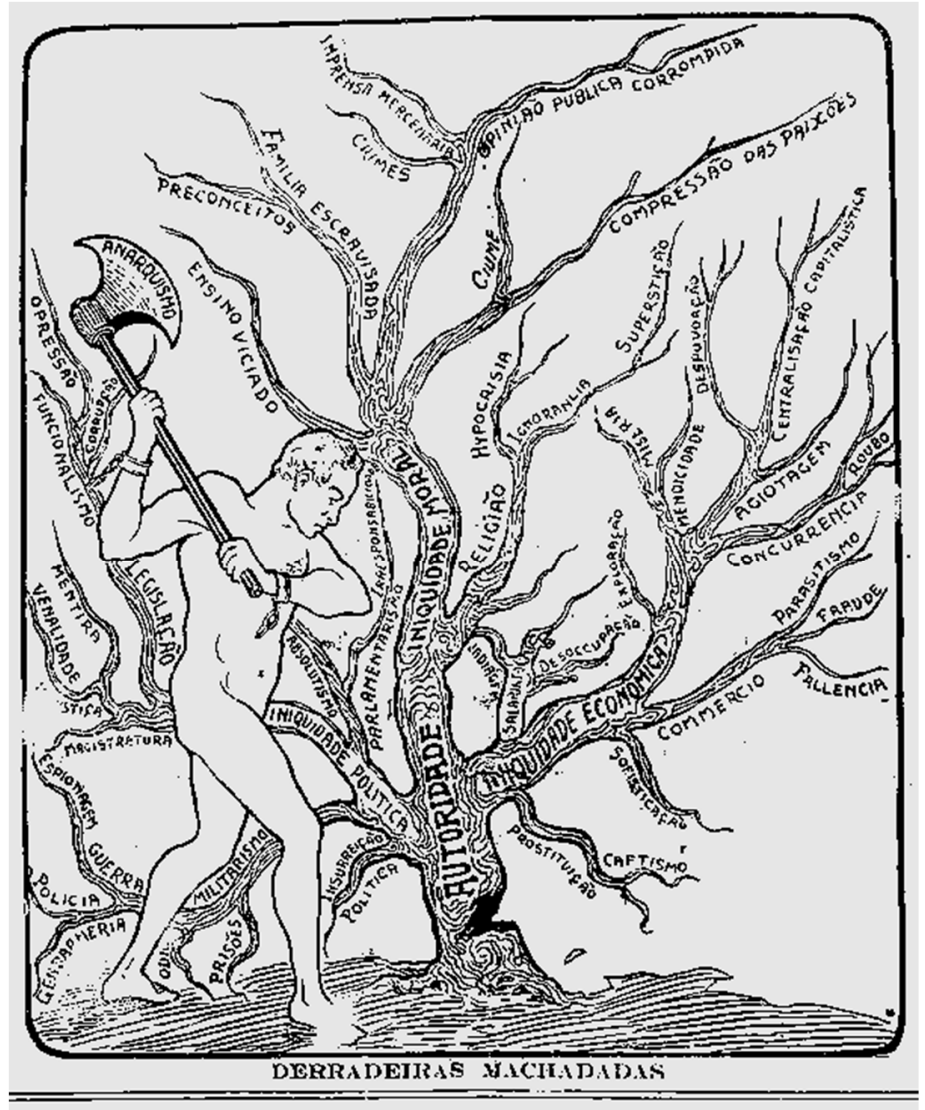

Fonte: A Plebe, São Paulo, n. 9, 11 ago. 1917, p. 1; A Guerra Social, Rio de Janeiro, n. 1, 11 ago. 1911, p. 1.

Seu título se encontra abaixo do desenho ("Derradeiras machadadas"). Vê-se um homem branco, forte, aparentemente jovem, nu, com correntes rompidas em seus punhos e com um machado nas mãos. Este está a cortar uma árvore seca, sem frutos. Para poder ser compreendida em sua essência, o desenhista indicou os significados dos símbolos (machado, tronco e galhos), ou seja, uma relação precisa entre o texto e a imagem. No machado, está escrito "Anarquismo", ou seja, um ideal com forte lâmina, capaz de cortar um mal. A árvore seca, sem folhas e frutos, por si só diz muito, mas foram acrescentadas à imagem, palavras. No tronco, "Autoridade", um dos princípios mais combatidos pelo ideal anarquista (Estado, Igreja, Exército, Poderes instituídos etc.). Desse tronco, saem três galhos principais: "Iniquidade Moral", "Iniquidade Econômica" e "Iniquidade Política". E, destes, suas subdivisões. No caso em questão, o galho da "Iniquidade Política" é foco deste trabalho. Lá, se encontram os seguintes galhos: "parlamentarismo", "corrupção", "mentira", "venalidade", "militarismo", "guerra", "magistratura", "legislação", "opressão", entre outros. O homem nu a simbolizar um novo homem, puro, despido dos vícios da sociedade burguesa. Estar nu e destruindo uma velha sociedade é mostrar um novo presente e um novo princípio. Portanto, somados à nudez, os grilhões simbolizam a liberdade desses mesmos vícios.

Seguindo a mesma direção, a maioria das imagens produzidas pela imprensa anarquista apresenta essa dinâmica. Abaixo, por exemplo, duas imagens carregadas de significados. Na Figura 5 (Liberdade, n. 31, jun. 1919, p. 1), vê-se, ao invés de um forte homem a cortar uma árvore, uma alegoria feminina. Com um longo vestido, ombros desnudos, descalça, em uma das mãos empunha uma tocha, da qual sai uma longa chama com a 
inscrição "Liberdade". Na outra mão, um livro, símbolo caro para os anarquistas, como veremos adiante. Mas a qual liberdade se refere a imagem? Aos pés da alegoria, com traços brancos, há diversos símbolos destruídos, que, somados ao ideal de liberdade, ajudam a compor a mensagem da imagem. Lá, estão o báculo, a bíblia, o crucifixo, um cadeado, a coroa (monarquia), um canhão e uma tábua onde está escrito "lei". Os valores religiosos, a prisão, a guerra, o regime político, as repressões policiais e legais inibiam a liberdade. Da mesma forma, a falta de conhecimento, do saber, era um importante instrumento de dominação.

Figura 5



Fonte: A Liberdade, Rio de Janeiro, n. 31, jun. 1919, p. 1.

Assim, em contraponto aos símbolos da sociedade capitalista, são construídos outros, de libertação, pois a tocha e o ensino/conhecimento científico rompem com os malefícios da sociedade burguesa, com o ensino viciado e repressor, limitador da criação e da liberdade intelectual e individual. Por fim, uma legenda-síntese da imagem: "Por terra todas as tiranias! Haverá Paz e bem-estar para todos".

Seguindo a mesma forma, a Figura 6, publicada em comemoração ao primeiro de maio na quarta e última página do jornal anticlerical $A$ Lanterna (São Paulo, n. 289, 1 maio 1916, p. 4), é repleta de detalhes importantes. O primeiro de maio em destaque dá a entender que houve uma adaptação da mesma para a publicação. No original, estaria escrita em outra língua ou foi produzida para outro evento? Frases básicas do pensamento libertário estavam presentes, como palavras-chave: "A emancipação há de ser obra da ação direta dos próprios trabalhadores"; "O homem livre sobre a terra livre"; "evolução". Adornando a imagem central, além das palavras, há as principais figuras que compuseram o pensamento anarquista (filósofos, escritores, jornalistas, educadores etc.): Kropotkin, Malatesta, Bakunin, Reclus, Luiza Michel, entre outros. Portanto, uma construção imagética harmoniosa.

$\mathrm{Na}$ imagem central, propriamente dita, uma produção mais detalhada que a anterior. A palavra "Liberdade" não mais faz parte da ilustração, mas há a mulher branca, com seus cabelos esvoaçantes, ombros nus, agora segurando uma tocha que emite uma forte luz, representando a clareza das ideias, a visão pura e objetiva da sociedade anarquista. Aos pés da dama, o báculo, o trono, a coroa, o crucifixo, a corrente e o cadeado, a espada e a baioneta, dois livros (um seria a bíblia?), a tábua das leis e, por fim, um saco de moedas. Portanto, esse 
conjunto de imagens, como na anterior, tinha o papel de inspirar e estimular. Estimular a leitura dos pensadores retratados, mostrar que seus escritos podiam se tornar realidade e que uma nova sociedade seria possível. Inspirar para a mobilização e fortalecer a unidade operária contra os inimigos de todos, o Capital (urbano e rural), o Estado e a Igreja, em síntese, o sistema capitalista burguês.

Figura 6

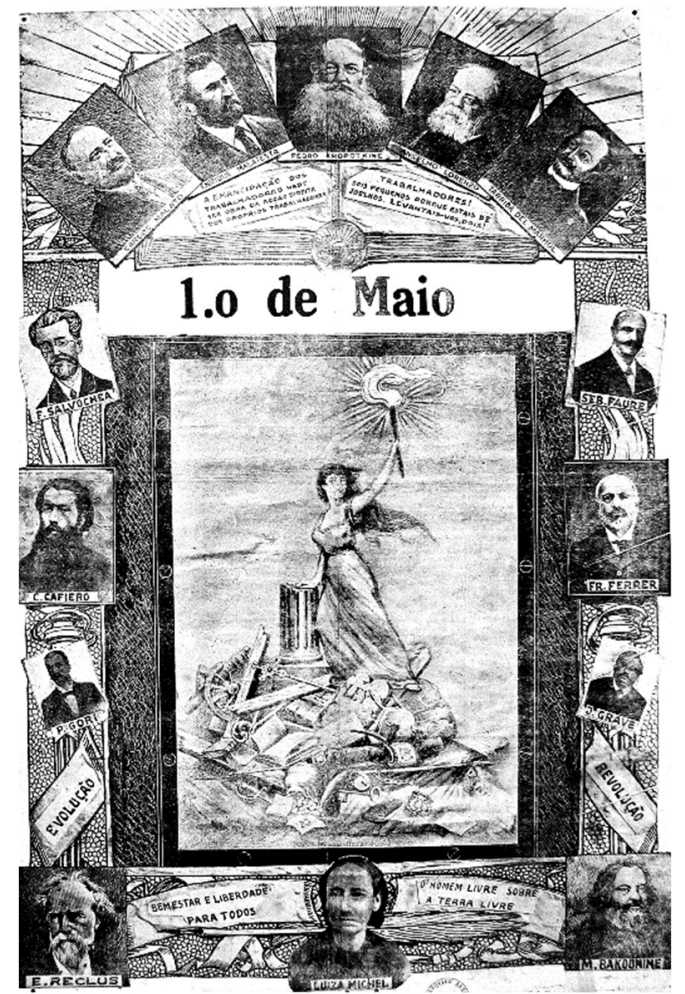

Fonte: A Lanterna, São Paulo, n. 289, 1 maio 1916, p. 4.

A Lei ("Lex"), como demonstraram as imagens, era vista pelos anarquistas como um dos instrumentos usados pelos detentores do poder para autorizar o uso da força e reprimir as ações individuais e coletivas da classe operária. Destaca-se que, entre os anos de 1890 a 1927, uma dezena de leis e decretos foram criados e aprovados com o intuito de controlar e reprimir os vadios, mendigos, desocupados e, principalmente, o movimento operário organizado ou não. A entrada de supostos anarquistas era controlada na fronteira, bem como leis autorizavam sua expulsão, muitas vezes em processos sumários. Isto sem falar das ações diretas levadas a cabo pelas associações patronais em conluio com a polícia, tais como a criação de listas negras feitas por ambos com os nomes dos líderes operários e estabelecimento de prisões dentro da própria fábrica. A imprensa, em especial a vinculada ao movimento operário, também sofreu intenso controle por decretos e leis. No período presidencial de Arthur Bernardes (1922-1926), o Brasil viveu sob Estado de Sítio em sua maior parte, ou seja, maior rigor e repressão aos movimentos e organizações operárias (ALVES, 1997, p. 28-29).

Existe no entretanto uma fera, um abutre,

Um monstro pavoroso, hediondo que se nutre

De lágrimas e sangue, é mais feroz que a hiena;

Não conhece remorso e não conhece pena.

Insensível à mágoa, às súplicas, à dor;

Forte como um juiz, cego como o terror. 
É inviolável; mata e fica sem castigo;

Ainda hoje o Estado é o seu melhor amigo.

Pois bem: eu que defendo o monstro que assassina

Contra o braço da força e contra a guilhotina,

Eu que proscrevo o algoz, eu exigi-lo-ei

Para enforcar somente esse bandido - A Lei.

(A Lei, Guerra Junqueiro, Do Crime).

(A GUERRA SOCIAL, Rio de Janeiro, 15 out. 1911, p. 2).

O movimento anarquista brasileiro se utilizou de várias formas de expressão cultural. Além dos jornais e das ações diretas (greves, boicotes etc.), havia também o teatro, a conferência, a poesia etc. Acima, a republicação de uma poesia de Guerra Junqueiro, escrita em 1875. Este autor teve, repetidas vezes, suas obras (ou trechos) publicadas nos jornais anarquistas. Na obra acima, apresentou o Estado como o melhor amigo da Lei. Seria a recíproca verdadeira? Definiu a Lei como um monstro sem remorsos ou pena, forte e que se alimentava das lágrimas e do sangue de suas vítimas. Matava sem punição. Ora, lembremonos do binômio da bandeira brasileira: Ordem e Progresso.

Em um artigo intitulado Noções do socialismo, de 1909, foi escrito que o Estado servia aos milionários, que reduzia à miséria os assalariados. O Estado era sinônimo de opressão e sua justiça estava à venda para os que poderiam pagar mais. Assim se expressava o autor:

O Estado é a exploração de milionários

Ao trabalho geral da humanidade

Reduzida à miséria dos salários

E a negação da própria liberdade.

É a justiça vendida a preços vários,

À desonra maior da sociedade

O direito do roubo aos proletários

Seus deveres, sem leis nem igualdade.

(A LIBERDADE, Rio de Janeiro, abr. 1909, p. 9).

Em outro texto, agora publicado em 1913, o articulista foi no mesmo sentido do artigo acima, pois, novamente, a lei era somente para alguns:

A igualdade perante a lei é uma mentira impingida pelos politiqueiros, interessados em manter as presentes instituições sociais. Todos os dias assistimos às proteções escandalosas que deixam ficar na impunidade os crimes mais abomináveis, enquanto outros sofrem todo o rigor da lei só porque são pobres e não têm proteção. Desnecessário é citar fatos, são tantos... (VOZ DO TRABALHADOR, 15 nov. 1913, p. 2). 
Figura 7

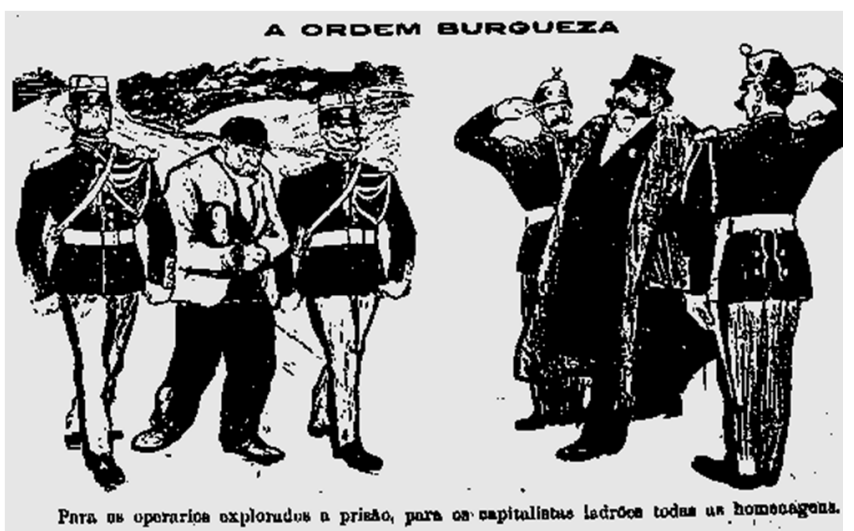

Fonte: A Plebe, São Paulo, ano 1,28 jul. 1917, p. 1.
Figura 8

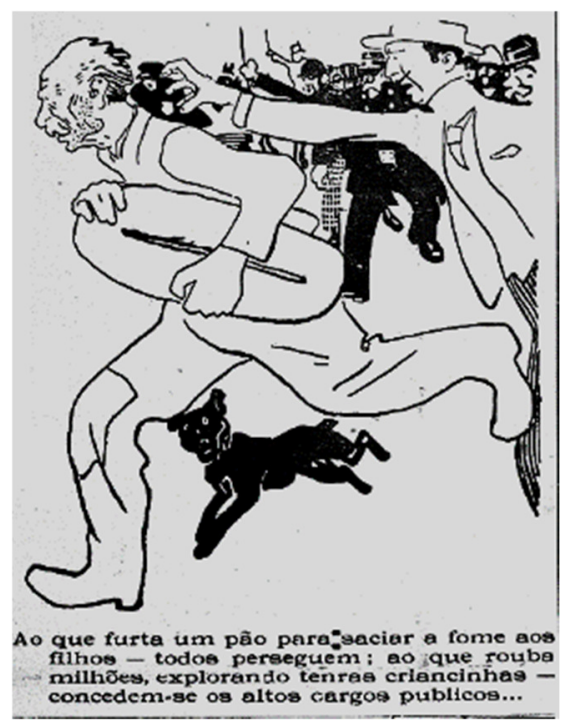

Fonte: A Guerra Social, Rio de Janeiro, n. 5 , 3 set. 1911 , p. 1.

As imagens acima acompanham o pensamento do artigo e ilustram bem a perspectiva anarquista acerca do poder policial e judiciário burguês. A Figura 7 ( $A$ Plebe, São Paulo, ano 1, 28 jul. 1917, p. 1) possui título ("A ordem burguesa"), uma legenda ("Para os operários explorados a prisão, para os capitalistas todas as homenagens") e foi dividida em dois momentos. O título resumiu bem a ideia da imagem, ou seja, a quem serve a "ordem", a quem ela se subordina. As imagens fortalecem o título, pois se pode ver, de um lado, um preso com um pão na mão, acompanhado por dois policiais. De outro lado, dois policiais (os mesmos?) fazendo continência ao patrão burguês (imagem de capitalista: obeso, bem vestido e de cartola). Abaixo da imagem, a legenda denunciando a "ordem" estabelecida na sociedade burguesa. Há uma relação direta entre os escritos e a imagem. O operário está cabisbaixo e mal trajado frente à elegância do patrão rico. Trata-se, portanto, de um conjunto de dualidade: rico $\mathrm{x}$ pobre, bem $\mathrm{x}$ mal, força $\mathrm{x}$ fraqueza, forte $\mathrm{x}$ fraco, obeso $\mathrm{x}$ magro, poder $\mathrm{x}$ submissão, explorador $x$ explorado, riqueza $x$ espoliação, elegante $x$ maltrapilho. Um discurso dualista facilmente entendido pela população, visto sua formação cristã, de visão do bem contra o mal. Procura-se, apenas, mudar as peças de lugar, forçar novos valores.

A Figura 8 (Guerra Social, n. 5, 3 set. 1911, p. 1), igualmente, apresenta a mesma mensagem, ou seja, o pobre que rouba para saciar a sede e a fome de seus filhos é perseguido e os capitalistas que exploram e roubam crianças de tenra idade nada sofrem, ao contrário, ganham cargos públicos. Novamente, o operário é mal trajado, magro e com ar abatido frente aos seus perseguidores, elegantes e sadios. A presença do cachorro reforça 0 ar de veracidade da cena.

A Figura 9 (O Debate, Rio de Janeiro, n. 5, ago. 1917, p. 1) possui título e legenda, deixando muito clara a mensagem. Apresenta um senhor da elite burguesa (não identificado), bem vestido e calçado, com volumosa barriga. O título se refere à figura ("barriga cheia"), e, somado à legenda abaixo da imagem ("Qual fome! O que há são fantasias de anarquistas..."), causa riso, pois há uma contradição explícita. Realmente, a figura não está passando fome, portanto, esta só pode ser fruto de fantasia de anarquistas mentirosos. 
Figura 9



Fonte: O Debate, Rio de Janeiro, n. 5, ago. 1917, p. 1.

Assim, o artista demonstra que não se faz necessária uma denúncia mostrando imagens de miséria. A contradição pode muito bem expressar uma verdade. Não é da "fome" do burguês que tratam os textos e as denúncias nos jornais anarquistas. Não é a "vida miserável" nos palacetes que preocupa as mentes dos libertários. Não é a "justiça injusta" aos capitalistas que denunciam as imagens deste texto. É a fome, a exploração, a miséria, as condições de vida e trabalho, a parcialidade da justiça burguesa, que fizeram surgir e expandir o ideário anarquista no seio da população operária.

A seguir, duas charges. A Figura 10 (Terra Livre, Lisboa, ano I, n. 3, 27 fev.1913, p. 4) é muito simples de ser entendida, pois Themis foi identificada como sinônimo de sistema jurídico. Com a espada pendendo para um lado, um dos olhos abertos, vendo muito bem os lados do conflito, uma das mãos livre da balança a receber um saco de dinheiro (propina), "A justiça" é desmascarada como parcial e corrupta. De um lado, o pobre, com suas roupas rasgadas e sapatos furados, é ameaçado pela Justiça; e, de outro, o capitalista burguês (alinhado, obeso e de cartola), comprando a sentença.

A Figura 11 (A Plebe, São Paulo, 23 jul. 1927, p. 1), contundente na percepção do papel espoliador do capital sobre os operários, é, também, repleta de detalhes. A Justiça está representada apenas pela balança, pois não há lei que impeça o esfolamento do operariado e o sistema capitalista assim é. A balança está totalmente desequilibrada. Sentada em um de seus pratos há a figura de um capitalista, este com cara de porco, gordo como um, usando sua vestimenta tradicional, calçado e com a cartola. Em seu peito, um enorme cifrão, fazendoo se assemelhar a um enorme saco de dinheiro, fonte de sua alegria. Ri, gargalha de felicidade por sua situação privilegiada. De outro lado, sem a presença do prato, pois o mesmo é desnecessário, há operários enforcados. A relação intrínseca entre a existência da riqueza e 
a fartura do burguês é clara. Desnuda uma situação vivida por grande parte da população, uma situação cruel, de escárnio e vil.

Figura 10

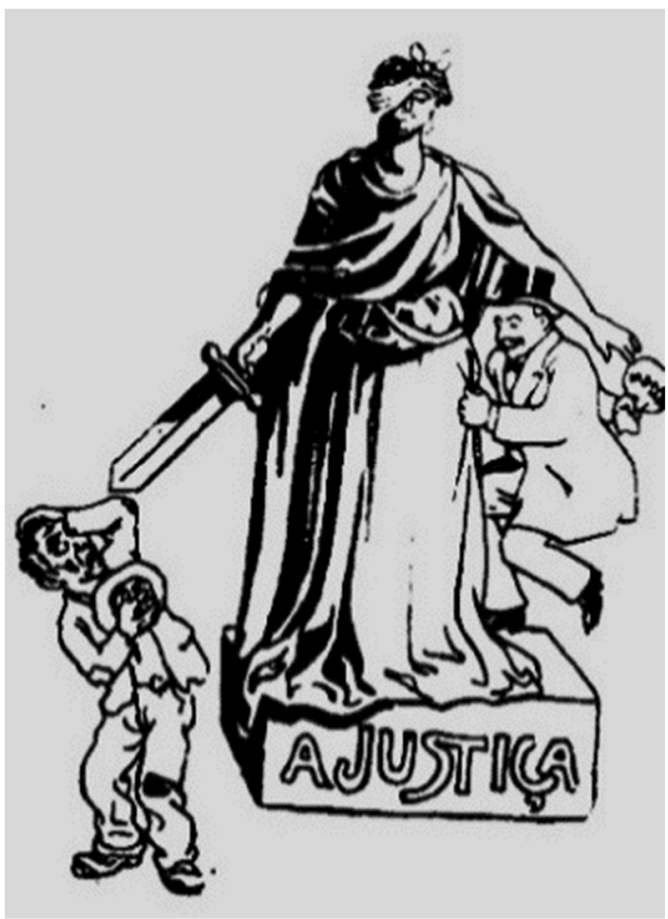

Fonte: Terra Livre, Lisboa, ano I, n. 3, 27 fev.1913, p. 4.

\section{Figura 11}

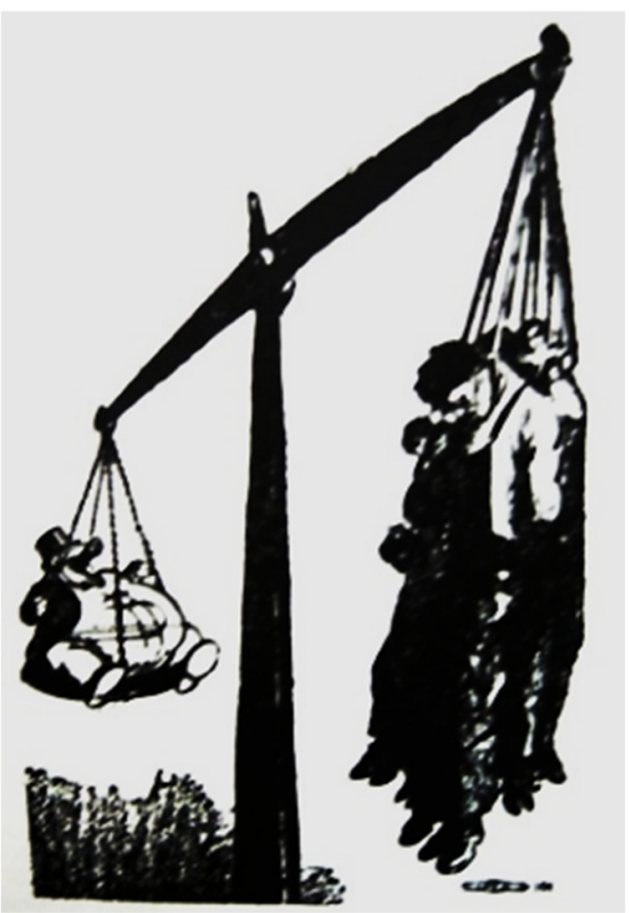

Fonte: A Plebe, São Paulo, 23 jul. 1927, p. 1.

Como parte da legislação repressiva, o uso da lei contra a greve foi uma constante. Se a polícia teria sido instituída para manter a ordem e evitar os abusos, na prática a realidade era outra. Ao enquadrar manifestações populares e operárias e as greves por salários e melhores condições de trabalho e vida como ações de desordem e não como um direito do cidadão, a lei só servia para garantir a manutenção do status quo, ou seja, a exploração que exerciam contra o operário. Mas a polícia também poderia ser passiva em muitos casos, como, por exemplo, quando da atuação de capangas nas eleições ou no empastelamento de jornais operários por elementos contrários aos seus ideários.

A Figura 12 é um bom exemplo. Embora o jornal O Parafuso não possa ser designado de anarquista, foi um jornal humorístico que apresentava críticas contundentes ao governo. Na presente imagem de capa - Figura 12 (O Parafuso, São Paulo, n. 170, 11 nov. 1919, p. 1), a charge possui um título ("O empastelamento de A Plebe") e apresenta a invasão e destruição da redação e da oficina gráfica do jornal operário anarquista A Plebe (São Paulo, 1917-1951). Os que atacam o jornal estão vestidos de roupas acima do padrão, o que caracteriza que não são operários. Mas chama a atenção a existência de policiais nas janelas, apenas observando o que estava ocorrendo, sem nenhuma reação e, pior, um deles sorrindo. 
Figura 12

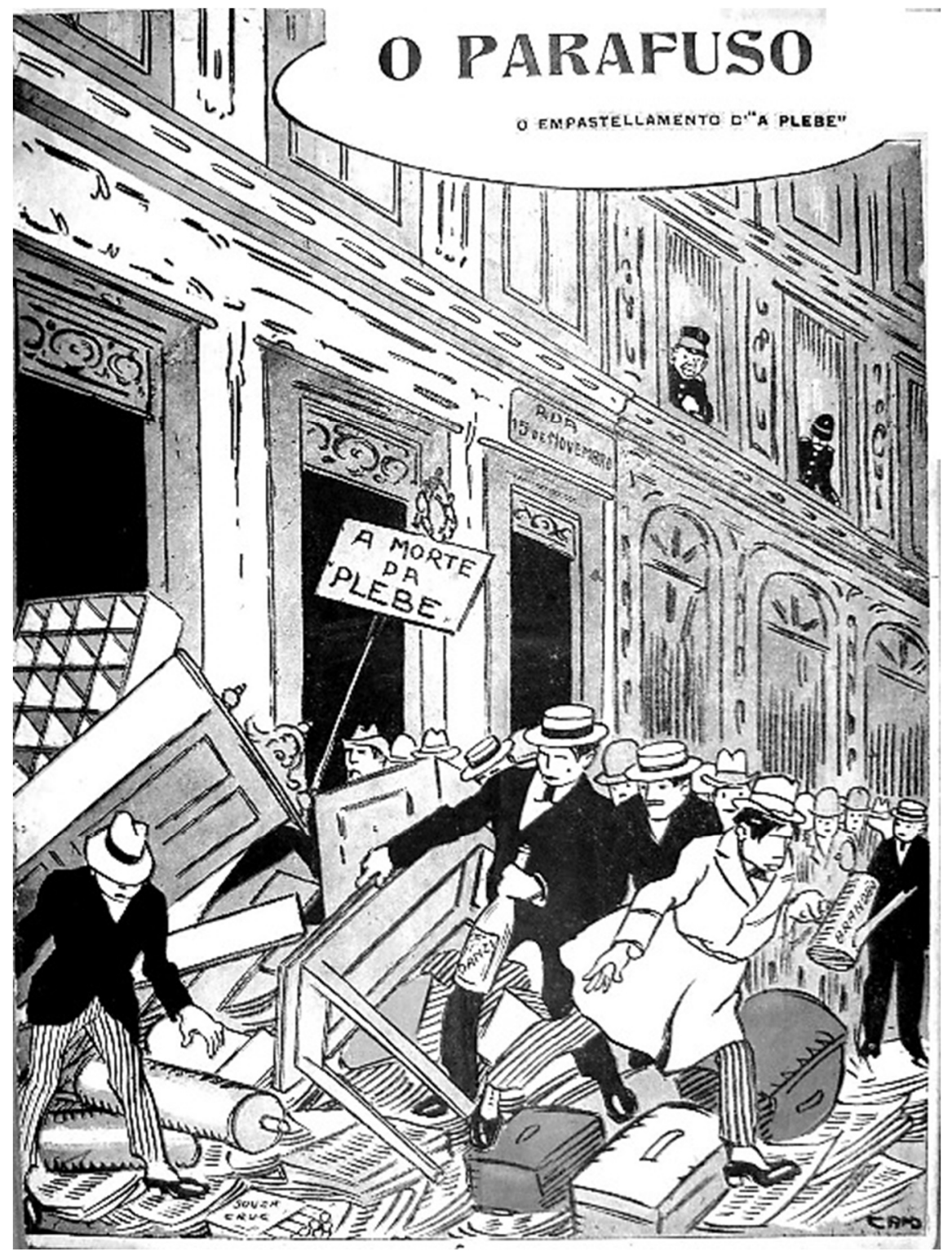

Fonte: O Parafuso, São Paulo, n. 170, 11 nov. 1919, p. 1.

Realiza-se, hoje, em todo o Brasil, a eleição para presidente da República...Toda a gente, porém, está farta de saber que absolutamente não é uma coisa séria [...]. Um colégio eleitoral [...] não é um lugar aonde qualquer cidadão pacífico possa ir, com a desejável segurança, depositar a patriótica cédula que leve o nome do sujeito escolhido para governar. Nada disso. É, antes, um covil de assassinos, um matadouro perfeito, aonde o eleitor penetra com o risco irremediável de perder a rica pele. Ora, não consta que os brasileiros em geral sejam pessoas duma prodigiosa coragem. Daí a sua abstenção quase unânime, aos sorteios eleitorais. $E$ daí, este inconcebível resultado: realizam-se eleições sem eleitores. (VOZ DO TRABALHADOR, 1 mar. 1914, p. 1). 
A citação acima, retirada do jornal $A$ Voz do Trabalhador ("A mentira chamada sufrágio"), órgão oficial da Confederação Brasileira Operária (COB), de 1914, somada às imagens abaixo, nos possibilita ter uma ideia de como eram representadas visualmente as eleições no Brasil.

A Figura 13 foi publicada no jornal $A$ Plebe ("A burla eleitoral"), de 26 de fevereiro de 1927. A distância temporal de 13 anos entre o referido texto e a imagem publicada em A Plebe não foi capaz de separar os fatos, pois ainda estão unidos. A Figura 14 foi publicada na primeira página do jornal Gazeta de Notícias, ano de 1900, ou seja, um periódico "burguês". Esta imagem possui um título ("As delícias do voto") e um diálogo. Com a ajuda de um amigo, o eleitor, com o voto nas mãos (como na Figura 13), volta para casa. Com a roupa em frangalhos e com as tripas à mostra, o eleitor afirma que não votaria mais enquanto fosse vivo, pois não pretendia nunca mais apanhar. Concluiu sua frase: "Só os mortos votam impunemente."

Portanto, tanto a grande imprensa, como as revistas ilustradas e os periódicos anarquistas tinham a mesma percepção do processo eleitoral: o controle do voto popular, indo ao encontro dos dados apresentados por Carvalho (1987), ou das palavras do romancista Lima Barreto (2008), ou seja, a abstenção eleitoral tomava caminhos para a extinção do eleitor.

Figura 13

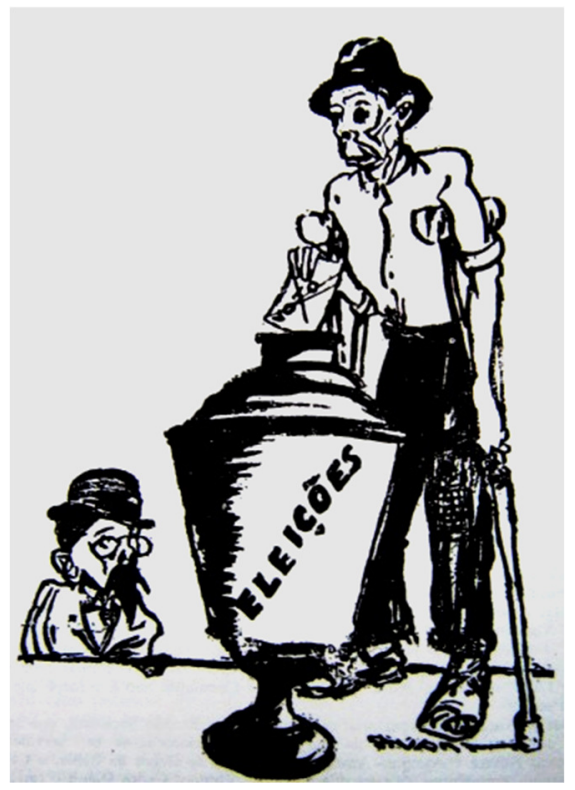

Fonte: A Plebe ("A burla eleitoral"), São Paulo, 26 fev.1927.
Figura 14

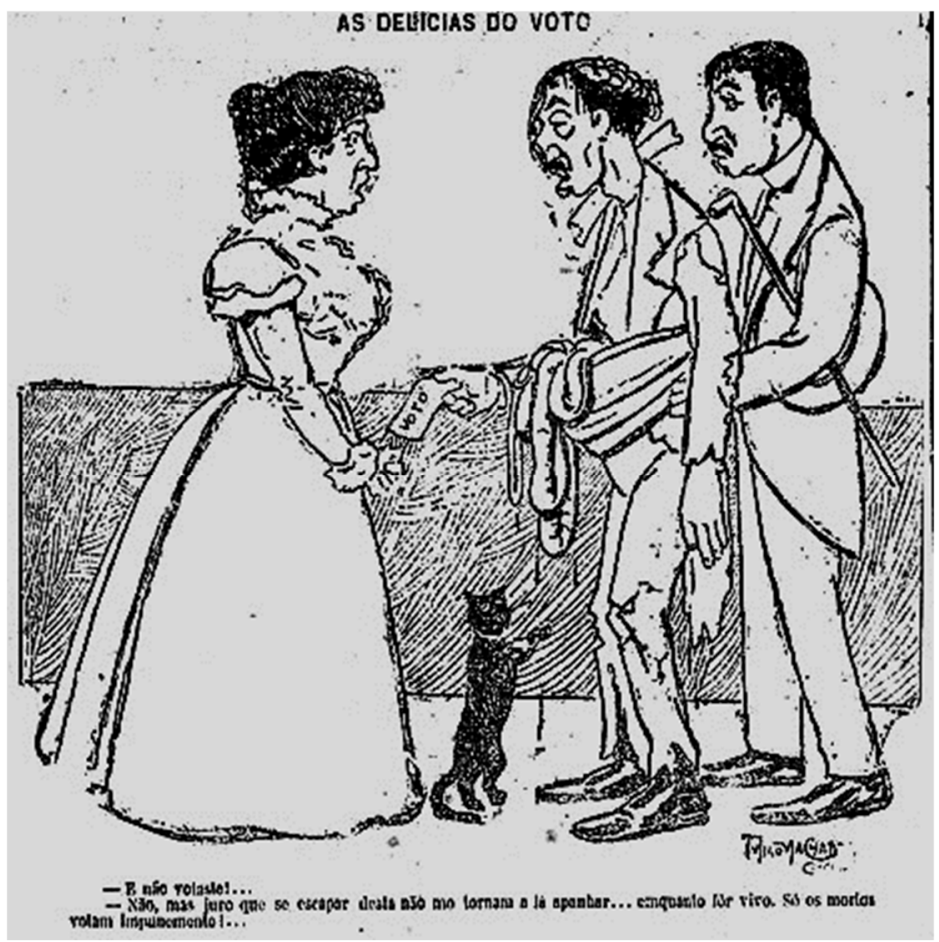

Fonte: Gazeta de Notícias, Rio de Janeiro 1900.

Mas as críticas vinculadas às fraudes também existiram em relação ao Tribunal do Júri. A imprensa anarquista deu destaque ao julgamento do assassino do importante político da República Velha, Pinheiro Machado, o criminoso Manuel de Paiva. Este foi condenado pelo Tribunal do Júri e a imprensa acusou o político Rivadávia Correa de subornar os jurados. 
A Figura 15 (O Debate, n. 4, 2 ago.1917, p. 1) destoa das outras charges publicadas pelo seu caráter intrínseco de humor. Seu autor, Fritz, era um caricaturista/chargista de revistas e jornais de humor:

Figura 15

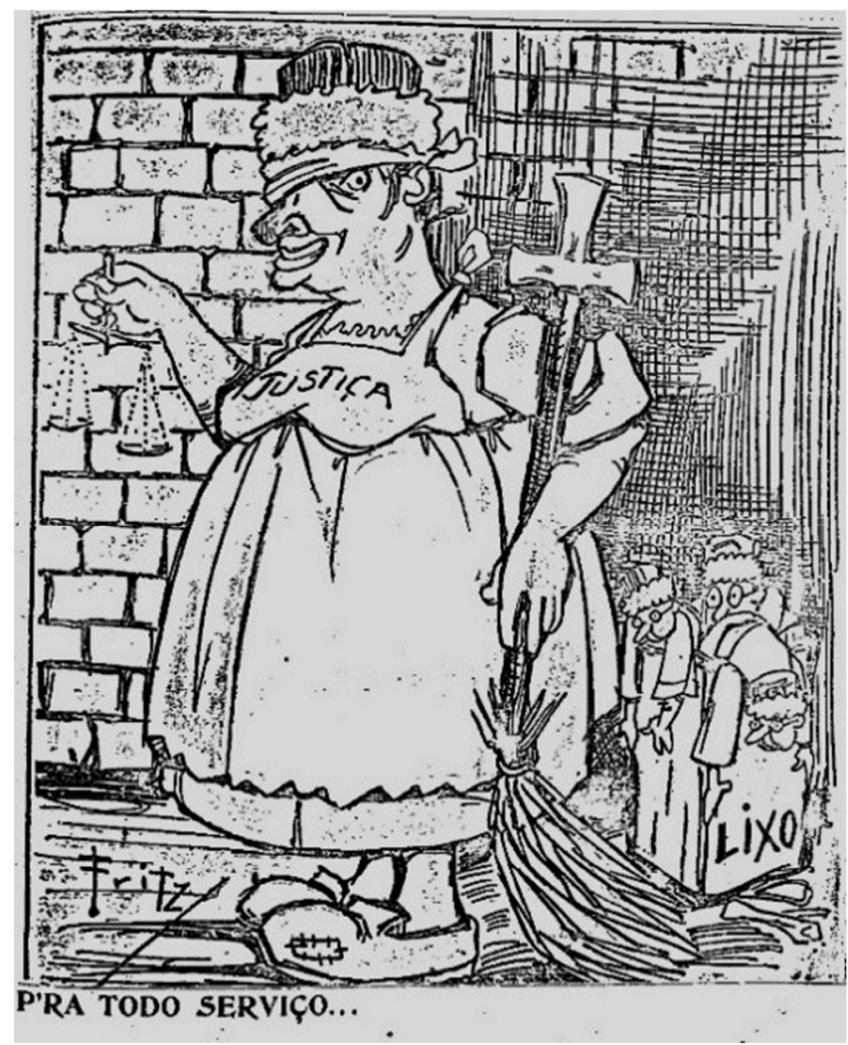

Fonte: O Debate, Rio de Janeiro, n. 4, 2 ago.1917, p. 1.

Não há certeza de que esta charge foi extraída de outro periódico ou feita exclusivamente para $O$ Debate. Themis (Justiça) virou uma serviçal da limpeza. Não é mais a bela jovem, e, sim, uma velha senhora, trajada de roupas simples e sapato remendado. A balança aparece desequilibrada, mostrando a "justiça" no ato praticado, e a venda só cobre um dos olhos, dando a entender que sabia muito bem o que estava fazendo. Um sorriso cínico é formado em seus lábios. Com graça, usa na cabeça um chapéu típico de juiz e sua espada se tornou uma vassoura. Com o título alvissareiro "Pra todo serviço", fez uma faxina no Poder Judiciário: para a lixeira, vários juízes (do Júri? do STF? Quem sabe?).

Mas a exceção não fez a regra. Dentro da estrutura prisional criada nesse período, há a Colônia Agrícola Clevelândia, localizada no rio Oiapoque, na divisa entre o Brasil e a Guiana Francesa. Criada pelo governo Epitácio Pessoa, em 1920, foi ocupada em grande número por presos no governo seguinte, de Arthur Bernardes. Lá chegaram cerca de mil presos, nos anos de 1921 a 1927, entre anarquistas, sindicalistas, militares rebeldes, mendigos, vagabundos, criminosos etc. Destes, 43\% morreram de disenteria, tuberculose, beribéri, entre outras doenças. Os que saíram vivos trouxeram a marca das doenças físicas e/ou mentais (PINHEIRO, 1991, p. 103; DULLES, 1977, p. 211). Essa prisão foi constantemente denunciada pela imprensa, não apenas anarquista.

A Figura 16 (A Plebe, São Paulo, ano 11, 12 fev. 1927, p. 1) trouxe uma grande reportagem, que contava com texto, fotografias, poesia e charge. O título da mesma traz os presos como "trabalhadores e militantes dedicados do proletariado". Ignorou os demais presos 
ou os considerou companheiros de luta e injustiçados pela ordem burguesa. A charge possuía um título denúncia: "Oiapoque! Símbolo da tirania burguesa". Abaixo da imagem, uma sentença: "Que os esqueletos dos companheiros dedicados que lá sucumbiram sirvam de símbolo na luta sem tréguas do proletariado". A imagem apresenta um corpo esquálido e uma caveira: uma morte para breve e uma morte já distante.

\section{Figura 16}

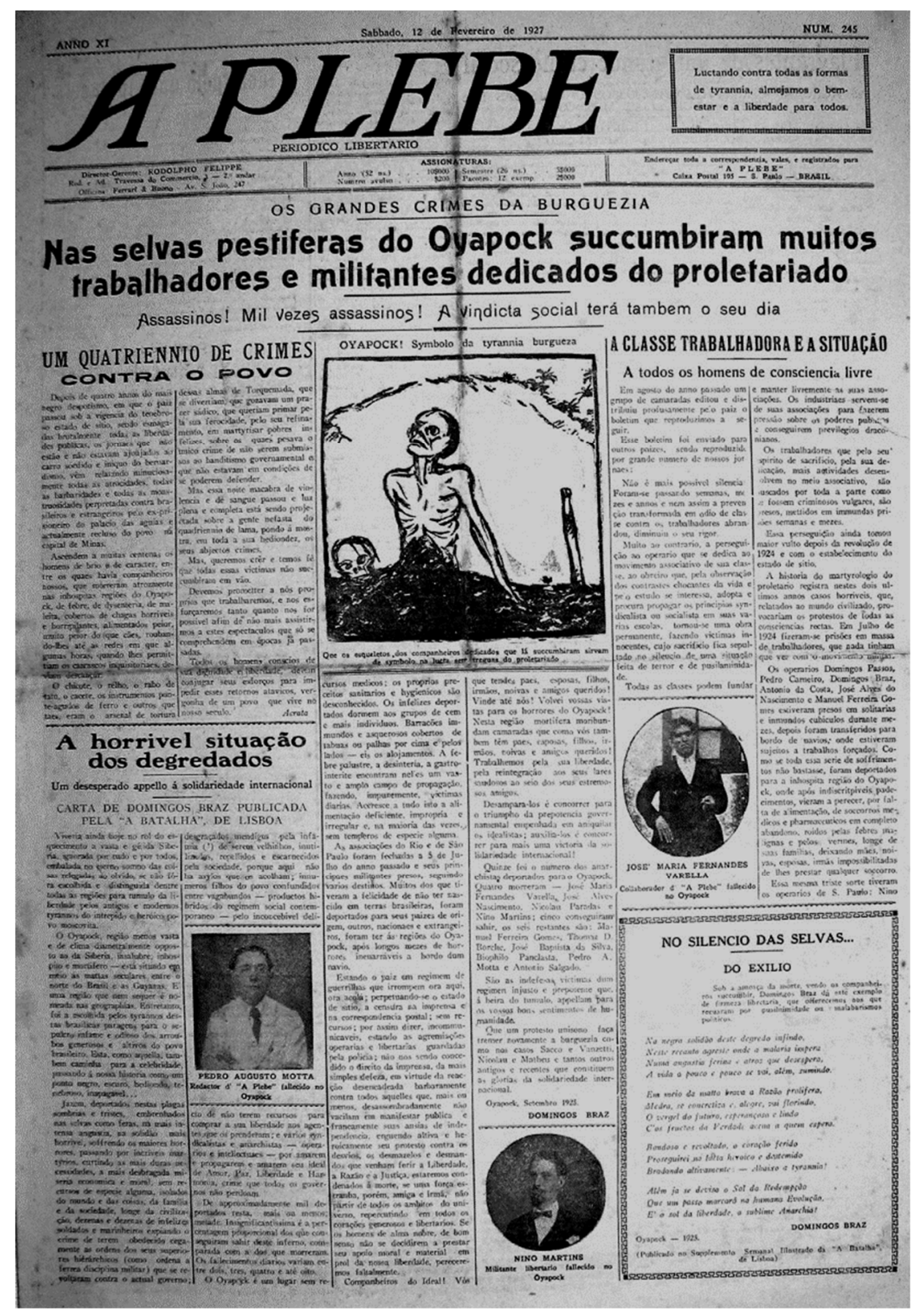

Fonte: A Plebe, São Paulo, ano 11, 12 fev. 1927, p. 1.

Relacionar um poder à prostituição, em uma sociedade moralista e dita cristã, como a brasileira no início do século $\mathrm{XX}$, era rebaixá-lo ao res do chão: “... O padre, o juiz, o comerciante, em suma, toda a corja que vive do trabalho alheio, se prostitui, porque vende a sua consciência, o seu caráter, e relega o que há de mais puro e insofismável na vida humana - a sua própria dignidade..." (A Guerra Social, Rio de Janeiro, 14 ago. 1912, p. 2). A crítica do jornal foi contundente, pois envolveu a Igreja, o Poder Judiciário e o comércio como irmãos 
na exploração da mão de obra, na venda de sua consciência (estranho um jornal anarquista apontar para a existência de alguma), ou seja, na prostituição de um possível caráter.

No decorrer deste tópico, foi possível ver a representação do operário, passivo, ingênuo, oprimido, enforcado, esmagado, espoliado pelo patrão e, também, do eleitor alquebrado. O certo a se afirmar é que, se, de um lado, havia o trabalhador explorado frente ao capitalista burguês gordo e rico (das charges), de outro, havia um novo homem nascendo (das ilustrações). Um trabalhador vencedor, consciente, libertador, forte perante seu inimigo. Assim como o anarquismo como ideal foi representado por uma mulher, um novo homem foi representado.

Figura 17

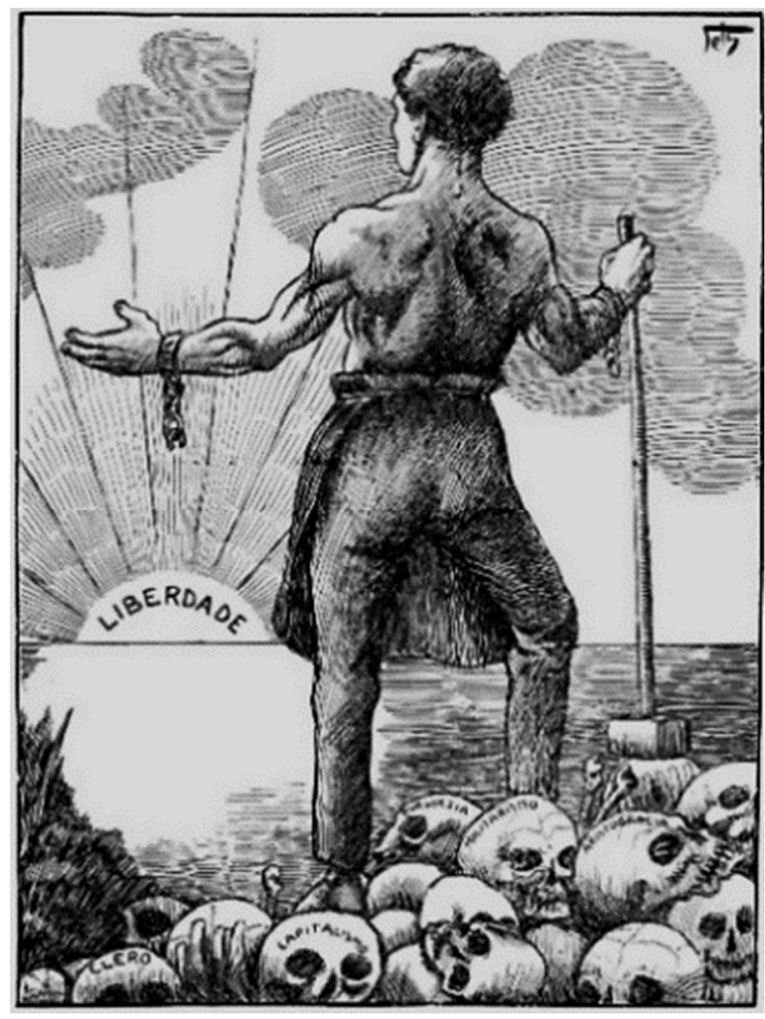

Fonte: Voz do Trabalhador, Rio de Janeiro, n. 1, 1 maio 1913, p. 1.

A Figura 17 (Voz do Trabalhador, Rio de Janeiro, n. 1, 1 maio 1913, p. 1), tal qual a imagem do homem nu com o machado da anarquia na mão (Figura 4) ou da mulher anarquia (Figuras 5 e 6), apresenta um homem (forte) com sua marreta em uma das mãos, que pisa sobre os escombros da velha sociedade, identificada em vários crânios (capitalismo, clero, burguesia, militarismo e aristocracia). Sem os grilhões - da opressão - que prendiam suas mãos, recebe os raios de um novo momento, o da liberdade econômica, política, social e cultural. A ausência explícita de uma referência à justiça chama a atenção, embora possa ser vista como serviçal da monarquia, do capitalismo e da burguesia.

A seguir, duas imagens de autoria de $\mathrm{M}$. Copllonch, um artista que viveu na cidade do Rio de Janeiro, aparentemente brasileiro, mas que pouca representatividade deixou. Ambas as ilustrações publicadas no mesmo ano, 1919. Ambas com mensagens muitos semelhantes. A Figura 18 (Grilhetas, Rio de Janeiro, ano 1, 5 maio 1919, p. 1) está vinculada à comemoração do Primeiro de Maio, data-símbolo da luta operária. Tal como a imagem anterior, sem referência à justiça, fica evidente, em especial tendo a imagem seguinte como referência, que ela está presente amplamente na mesma. Duas fileiras de forcas, muitas com 
cadáveres dependurados, transmitem dor e repulsa. O responsável por isto está no centro da imagem. O carrasco, com os braços cruzados, espera novas vítimas. No tronco, e em seu entorno, os símbolos do terrorismo estatal. Em cima do tronco, o instrumento da morte, o machado; ao chão, de um lado, sacos de dinheiro (a terceira imagem com esse importante detalhe), e, de outro, caveiras, mais vítimas da opressão. Mas, caminhando em direção do carrasco, um casal abraçado. Ele, em uma das mãos, carrega uma bandeira (provavelmente vermelha), e, na outra mão, um livro, cujo título é "Humanidade". Ela, a liberar sementes que germinarão no solo, talvez simbolizando a nova sociedade a nascer. Fisicamente, são iguais, denotando uma igualdade e respeito entre os sexos Por fim, as nuvens de fumaça ao fundo, reforçando a mensagem de mudanças políticas e sociais que advirão.

\section{Figura 18}



Fonte: Grilhetas, Rio de Janeiro, ano 1, 5 maio 1919, p. 1.

Já na Figura 19, capa do jornal $A$ Liberdade (Rio de Janeiro, ano III, abr. 1919), um "periódico de crítica social e noticioso", sob direção de Pedro Matera ${ }^{44}$, a justiça está expressa, pois na forca está escrito "Justiça Burguesa". Uma imagem forte, já que há um homem sendo sufocado por outro e muitos crânios em uma cesta.

Uma análise cuidadosa nos possibilita ver bem a mensagem pretendida pelo autor e os signos utilizados para compô-la. Essa imagem de capa é composta de vários signos e duas

\footnotetext{
${ }^{44}$ Sobre Pedro Matera, ver: <https://marquesdacosta.files.wordpress.com/2011/12/emece_20.pdf>. Acesso em: 12 jun. 2017.
} 
legendas. A primeira, quem sabe, do artista, diz: "É chegada a hora do 'carrasco' ". Curiosas as aspas na palavra "carrasco", a marcar a referência como uma metáfora, pois o personagem representaria algo maior que um modesto executor de pena capital. Assim, a escrita se refere ao próprio sistema capitalista, opressor, assassino, o carrasco dos direitos e das liberdades do povo. A segunda frase ("o proletário não suporta mais!"), exclamativa, é uma afirmação de que o proletariado não aguentaria mais a opressão que vivia. Esta frase destoa da primeira frase e, mesmo, da imagem em si. A imagem é presente e aponta para o futuro. O presente é a morte do carrasco e o futuro é a nova sociedade nascente, representada pelo sol ao fundo. No machado está escrita a palavra "governo", que, somada à escrita na forca ("justiça burguesa"), dá a entender que o primeiro executava as ordens da segunda. Portanto, um estado burguês atendendo aos anseios de uma justiça burguesa (ou vice-versa?). O cesto repleto de crânios até a boca dá uma dimensão da violência exercida contra o proletariado. Mas, contrapondo-se aos crânios, homens e mulheres, abraçados, caminham para um novo devir.

Figura 19

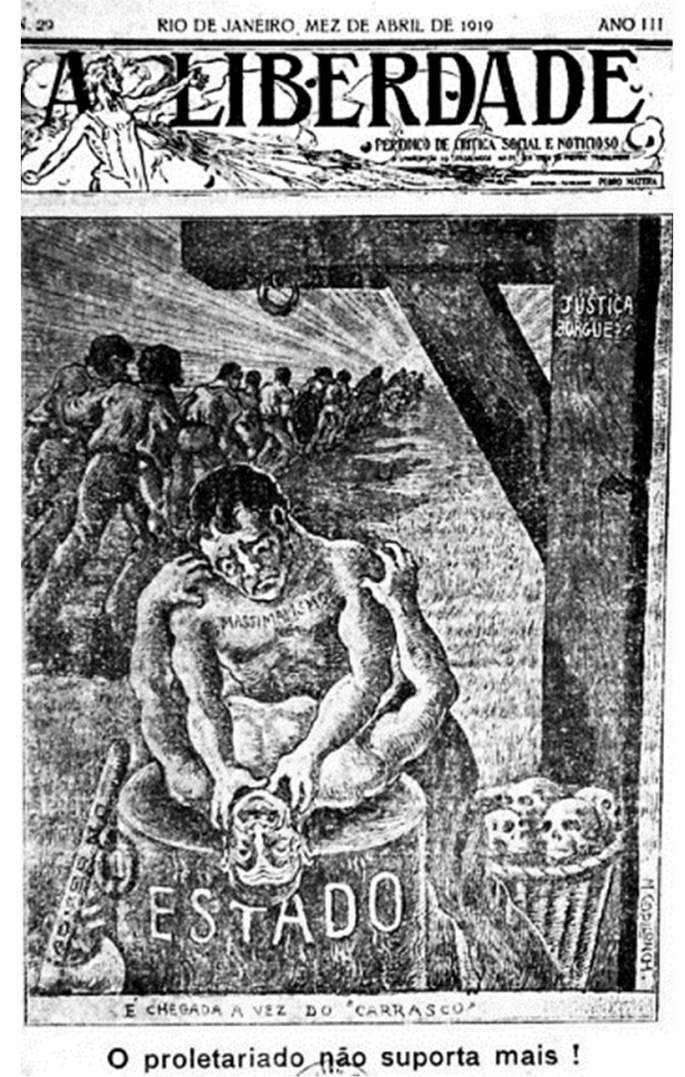

Fonte: A Liberdade, Rio de Janeiro, ano III, abr. 1919.

\section{IV.Conclusão}

O uso de ilustrações, charges e caricaturas não foi invenção da imprensa anarquista, mas, na medida do possível, foi bem aproveitado por ela. Em um universo de trabalhadores analfabetos, a imagem foi vista como um importante instrumento educacional para a difusão do ideário anarquista e como denunciador de um sistema capitalista opressor e espoliador.

Neste texto, a relação da expressão visual com a Justiça, o Poder Judiciário, foi a tônica, o seu alicerce. Do ponto de vista didático, foi mostrada a composição das imagens (títulos, legendas etc.), em um tipo de imprensa possuidora de um ideário, a anarquista. 
$\mathrm{Na}$ imprensa anarquista, a Justiça, o Poder Judiciário, as Leis criadas pelos poderes Executivo e Legislativo foram a base das críticas. Não era possível visualizar uma sociedade justa com uma Justiça parcial. Assim, as charges e demais formas de ilustração construídas por essa imprensa iam no sentido de denunciar, poucas vezes com o riso, as condições de exploração do trabalhador, sua falta de liberdade de expressão e organização, a existência de leis repressivas, elaboradas pelos capitalistas, pelos patrões para o seu próprio bem (Código Penal, lei de expulsão, organização patronal em conluio com a polícia etc.). Isso sem citar a criação e implementação de uma prisão no Oiapoque, com índice de mortalidade de $43 \%$ dos encarcerados.

Pode-se afirmar que a imagem (charge ou ilustração) recebeu por parte da imprensa anarquista um destaque na medida do acesso à tecnologia da época e das verbas disponíveis. Patrão obeso, bem vestido e rico graças ao operário faminto, malvestido e explorado. Forcas, machados, saco de dinheiro e crânios reforçavam as mensagens de denúncia de um sistema opressor. Ilustrações que traziam o ideal de liberdade, igualdade e fraternidade em um novo mundo com um novo ser. Um novo homem anarquista, forte e feliz, em um mundo livre de autoridades, iniquidades, exploração e mentiras. Dentro dessa perspectiva de denúncias e de uma nova sociedade, a Justiça, o Poder Judiciário foi apresentado como opressor, repressor, do lado de uma classe social e inimigo de outra.

\section{Referências}

\section{Periódicos:}

Jornal A Lanterna, São Paulo, 1901-1916.

Jornal A Guerra Social, Rio de Janeiro, 1911-1912.

Jornal O Debate, Rio de Janeiro, 1917.

Jornal A Plebe, São Paulo, 1917-1922.

Jornal A Vida, Rio de Janeiro, 1914-1915.

Jornal O Combate, São Paulo, 1915-1927.

Jornal O Parafuso, São Paulo, 1917-1921.

Jornal Terra Livre, Lisboa, 1913.

Jornal A Aurora, Rio de Janeiro, 1902; 1913-1915.

Jornal Alvorada, Rio de Janeiro, 1919-1921.

Jornal Spartacus, Rio de Janeiro, 1919-1920.

Jornal Amigo do Povo, Rio de Janeiro, 1902-1904.

Jornal O Cosmopolita, Rio de Janeiro, 1916-1918.

Jornal Na Barricada, Rio de Janeiro, 1915-1916.

Jornal A Liberdade, Rio de Janeiro, 1919.

Jornal Grilhetas, Rio de Janeiro, 1919.

\section{Fontes secundárias:}

ABREU, Carlos. Hacia una definición de caricatura. Revista Latina de Comunicación

Social, San Cristóbal de La Laguna, n. 40, abr. 2001. Disponível em:

<http://www.revistalatinacs.org/2001/latina40abr/102cabreuVII.htm>. Acesso em: 12 jun. 2017.

ALBERTI, Verena. O riso e o risível. Rio de Janeiro: Zahar, 1999.

ALVES, Paulo. A verdade da repressão. Práticas penais e outras estratégias na ordem republicana (1891-1927), s/l., s/ed., 1997. 
BACZKO, Bronislaw. Imaginação Social. In: ENCICLOPÉDIA EINAUDI. Antropos-Homem, v. 5. Lisboa: Imprensa Nacional-Casa da Moeda, 1985.

BAKTHIN, Mikhail. A cultura popular na Idade Média e no Renascimento. 2. ed. São Paulo: Hucitec; Brasília: Edunb, 1993.

BATALHA, Claudio. O movimento operário na Primeira República. Rio de Janeiro: Zahar, 2000.

BEIGUELMAN, Paula. Os companheiros de São Paulo. São Paulo: Global, 1981.

BURKE, Peter. Testemunha ocular. História e imagem. Bauru: EDUSC, 2004.

CHARTIER, Roger A história cultural: entre práticas e representações. Rio de Janeiro: Bertrand, 1985.

CARVALHO, José Murilo de. Os bestializados. São Paulo: Companhia das Letras, 1987.

DULLES, John W. F. Anarquistas e comunistas no Brasil. 2. ed. Rio de Janeiro: Nova Fronteira, 1977.

FAUSTO, Boris. Trabalho e conflito urbano no Brasil (1890-1920). São Paulo: Difel, s/d.

FONSECA, J. da. Caricatura: a imagem gráfica do humor. Porto Alegre: Artes e Ofícios, 1999.

GAWRYSZEWSKI, Alberto. Conceito de caricatura: não tem graça nenhuma. Domínios da imagem. Londrina, n. 2, p. 7-26, maio 2008. Disponível :

$<$ http://www.uel.br/revistas/dominiosdaimagem/index.php/dominios/article/viewFile/27/13>.

GOES, Maria Conceição Pinto de. A formação da classe trabalhadora: movimento anarquista no Rio de Janeiro, 1888-1911. Rio de Janeiro: Zahar, 1988.

GOMES, Angela de Castro. A invenção do trabalhismo. Rio de Janeiro: IUPERJ; Vértice, 1988.

JOMINI, Regina Celia Mazoni. Uma educação para a solidariedade: contribuição ao estudo das concepções e realizações educacionais dos anarquistas na República Velha, Campinas: Pontes, c1990.

LIMA, Herman. História da caricatura no Brasil, Rio de Janeiro: José Olímpio, 1963. V. 1.

LIMA BARRETO. Clara dos Anjos. São Paulo: Paulus, 2008.

MARAM, Sheldon Leslie. Anarquistas, imigrantes e o movimento operário no Brasil (1980-1920). Rio de Janeiro: Paz e Terra, 1979.

PESAVENTO, Sandra Jatahy. História \& história cultural. Belo Horizonte: Autêntica. 2005.

PINHEIRO, Paulo Sérgio. Estatégias da ilusão (1922-1935). São Paulo: Companhia das Letras, 1991. 
RIANI, Camilo. Tá rindo do quê? Um mergulho nos salões de humor de Piracicaba. Piracicaba: UNIMEP, 2002.

RODRIGUES, Edgar. Alvorada operária. Rio de Janeiro: Edições Mundo Livre, 1970.

Os libertários: ideias e experiências anárquicas. Petrópolis: Vozes, 1988.

SILVA, Marcos. Caricata república, São Paulo: Marco Zero, 1990.

TEIXEIRA, Luiz G. S. O traço como texto: a história da charge no Rio de Janeiro de 1860 a 1930. Rio de Janeiro: Fundação Casa de Rui Barbosa, 2001.

Teses e dissertações:

ABDELMALACK, Genny. Momentos da história do Brasil através da caricatura (1900/37). 1991. Dissertação (Mestrado em Artes) - Departamento de Comunicações e Artes, Universidade de São Paulo, São Paulo, 1991.

AGOSTINHO, Aucione Torres. A charge. 1993. Tese (Doutorado em Artes) - Escola de Comunicação e Artes, Universidade de São Paulo, São Paulo, 1993.

CAMARGO, Daisy. 0 teatro do medo: a encenação de um pesadelo nas imagens do periódico A Plebe (1917-1951). 1988. Dissertação (Mestrado em História) - Programa de Estudos Pós-Graduados em História, Pontifícia Universidade Católica de São Paulo, São Paulo, 1988.

FERNANDES, Marisa. Sob os focos d'Lanterna. Mulher na imprensa anticlerical 1909/16. 1997. Dissertação (Mestrado em História) - Universidade de São Paulo, São Paulo, 1997.

GALLOTTA, Brás Ciro. O Parafuso. Humor e crítica na imprensa paulistana. 1915-1921. 1997. Dissertação (Mestrado em História) - Programa de Estudos Pós-Graduados em História, Pontifícia Universidade Católica de São Paulo, São Paulo, 1997.

MIGUEZ, Íris Carolina Lopes de Souza. Arranjos combinatórios. A charge nos estratagemas da identidade do jornal. 2003. Dissertação (Mestrado em Comunicação e Semiótica) - Programa de Estudos Pós-Graduados em Comunicação e Semiótica, Pontifícia Universidade Católica de São Paulo, São Paulo, 2003.

NERY, João Elias. Charge e caricatura na construção de imagens públicas. 1998. Tese (Doutorado em Comunicação e Semiótica) - Programa de Estudos Pós-Graduados em Comunicação e Semiótica, Pontifícia Universidade Católica de São Paulo, São Paulo, 1998.

PEROTTI, Ivane Laurete. Por uma tipologia do humor. Humor na política, política do humor. 1995. Dissertação (Mestrado em Linguística). Programa de Pós-Graduação em Linguística, Universidade Federal de Santa Catarina, Florianópolis, 1995.

SOUZA, Luciana C. Pagliarini de. Charge política: o poder e a fenda. 1986. Dissertação (Mestrado em Comunicação e Semiótica) - Programa de Estudos Pós-Graduados em Comunicação e Semiótica, Pontifícia Universidade Católica de São Paulo, São Paulo, 1986. 
WAGNER, Fernanda de Moraes Ramos. Charge: a arte satírica da comunicação. 2002. Dissertação (Mestrado em Comunicação) - Escola de Comunicação, Universidade Federal do Rio de Janeiro, Rio de Janeiro, 2002.

Recebido em julho de 2017. Aprovado em julho de 2018. 